\title{
Programs for children The neglected world
}

\author{
RIRIS K. TOHA-SARUMPAET
}

\begin{abstract}
${ }^{1}$
What do children watch on Indonesian television? This article tries to answer this question in the conviction that TV shows made for children require an understanding of their needs in order to grow, motorically, cognitively, psychologically, socially, and culturally. From my own fieldwork and research done on the data provided by my informants, I found that on television during the time slot set for children there are shows that are not intended for children to watch. I also found that children enjoy two favourite television shows in Indonesia the most, which are not programs designated for children. The conclusion is that Indonesian television pays little attention to children's needs, and children are neglected.
\end{abstract}

KEYWORDS

Children television shows, Indonesian television, Opera van Java, Islam KTP.

\section{INTRODUCTION ${ }^{2}$}

In the present era of mass communication, the media has a crucial role in the life of children: apart from providing entertainment, it also directly affects their cognitive and psychological development. We need to accept that children are a specific group of people with special needs. When talking

1 This article is based on the research "Study of Children's Stories", which I conducted with my students in 2009-2010 and 2010-2011 at the Faculty of Humanities, University of Indonesia. The first part was delivered at the National Seminar "Children Shows" organized by the Department of Literature and PPKB of the Faculty of Humanities, Depok, 11 May 2010. The second part was delivered at a seminar of the same name, also in Depok on 28 April 2011. I would like to express my gratitude to Ratna Djumala and all the other participants of the course on the Study of Children's Literature 2009-2010 and 2010-2011 who, with delight and much furor and emotion, tried to critically read/watch, discuss, and gather the materials needed for this article.

$2 \quad$ I would like to thank Dr. Dick van der Meij for his English translation of my article.

RIRIS K. TOHA-SARUMPAET, professor in literature, is a staff member of the Literary Department, Faculty of Humanities, University of Indonesia. Her interests are drama, poetry, and Children's Literature. She is the author of Pedoman Penelitian Sastra Anak (Jakarta: Yayasan Pustaka Obor. 2010). Riris K. Toha-Sarumpaet may be contacted at: riris-sarumpaet@indo.net.id.

C 2012 Faculty of Humanities, University of Indonesia 
of children we should therefore take these special needs into consideration. This means that we are concerned here with first-class programs that offer exemplary models and norms to assist children's psychological, social, and cultural development. Adults have to help and guide children in order to maximize their developments in these fields. ${ }^{3}$ Growing children are trained in phases to introduce them into society and this requires the mastering verbal and non-verbal language, attitudes, values, thoughts, skills and general knowledge as well as many other social-cultural essentials. Children obtain all the information they need to process from outside themselves and mostly they get it from their families, schools, playmates, and the mass media. Thus, in this study, we need to include the many communication media as "agents of children's socialization because, like their families, schools, and playmates it also offers information and exemplary models of conduct in the social and cultural contexts of children. Because television is especially near at hand and thus easily enjoyed through its visual and verbal imagery that effortlessly captures children's attention, experts state that - from all mass media available - television is the most influential" (Brown 1976: 20).

Much research has been done on the impact television has on children. In general, researchers agree that television has become an agent of socialization, an "adult supervisor" that provides knowledge about ways of life. Shows aired on television introduce children to the large number of roles and issues from the world of adults (Melody 1973; Palmer 1988; Berry and Asamen 1993; Yusuf 2010). A plethora of myths about television and children has been circulating since television was introduced in the 1950s. This discussion is still going on at present with all the extraordinary, digital sophistication that amazes and frightens many people: how do children use and respond to this, to what degree are they influenced by it, and how, and to what extent do children change because of television? There is much pro and contra about whether television's influence on children is positive or negative. Some experts are concerned with television's capacity to enthral children, and they fear that television may desensitize children. On the other hand, there is also a compelling theory that television has developed into some sort of central focus of social significance and communal context (Nodelman and Reimer 2003; Fiske and Hartley 1978; Adams 1992). Using earlier research as their point of departure, Gunter and McAleer (1997), in their turn, arrived at the conclusion that television - apart from all its possible weaknesses - can also have a positive influence and may even provide children with opportunities.

The commotion around the issue of television is also closely connected with education, especially children's academic development and achievements (Rice and Woodsmall 1988; Clarke and Kurtz-Costez 1997; Razel 2001). In any case, already for a long time, television has been considered "to cause problems" such as causing viewers to be desensitized (Cline et al. 1973), disseminating sex and violence (Kitley 2001) and thus, invariably, television

3 Related to this, children urgently and consistently require adult's "guidance" in their choice of reading materials. See Riris K. Sarumpaet, Bacaan Anak, Jakarta, Pustaka Jaya, 1976. 
has remained an "enemy of the family", and "has to be used wisely", or even "has to be watched carefully" (Nugroho 2005; Fabes et al. 1989; Anderson et al. 2001). Because of these and other similar issues, Schultze (1994), Chen (1996) and Shin et al. (2006) as well as many other experts, have also tried to propose ways to overcome the problem of television which delights but also burdens the family. The polemic around television is thus far from over and has instead become more urgent because of the increasingly incredible growth in technological sophistication and rapid social change.

This article sets forth what children in Indonesia watch and tries to discuss some favourite show broadcast on Indonesian television, while narrowing it further down to two adult shows Indonesian families love watching. The article is written with the consideration that, although much research has been done, Indonesian society remains rather ignorant of the struggle or even the controversy there is around television and is badly informed about children shows in Indonesia. The questions therefore are: What do children watch? Are Indonesians aware of the fact that the media rules our live? I hope this article is able to introduce some of the issues around what children watch on TV in Indonesia.

\section{CONTEMPORARY TELEVISION SHOWS: A GENERAL OVERVIEW}

Although this article focuses on shows aired on television in Jakarta, I believe that children enjoy most of these shows outside Jakarta, too. My point of departure for saying this is that everything the eyes can see - whether people in the immediate surroundings, foods on the table, transport passing the house, overflowing dust bins, stiffly lined-up shop houses, malls, dirty dwellings in narrow lanes, pet rabbits, piles of newspapers next to the sofa, and everything on television, nice or not, is a show and thus an agent of children's socialization. ${ }^{4}$ In this case, I believe that, because they are a kind of shows, all these influence children and add to their development into mature human beings.

Virtually every household in Jakarta has at least one television set, and the television has become the most important household appliance in presentday society. It is important to add to this the increasingly complex and rapid technological sophistication there is now. Through the introduction of the internet, urban dwellers no longer have to sit in front of their television at home in order to watch their favourite programs. As long as there is an internet connection, they can watch anything anywhere on their laptops or mobile telephones. ${ }^{5}$ Let us have a look at the general picture that emerges after

4 Do not forget the large numbers of magazines, films, video, games, musical performances, sports events, and even demonstrations and strikes which also form parts of what children watch.

5 This is why every child that has been born after 1960 in Indonesia is believed to have been raised and educated by television. More so, through the availability of contemporary increasingly more sophisticated information technology, every child in Jakarta and in all other cities and even villages in Indonesia can enjoy the television on their mobile phones. 
considering the substances and the airing times of the television programs of Wednesday, 10 February 2010 from eleven television stations in Jakarta.

TVRI (Televisi Republik Indonesia) is the oldest television station in Indonesia and still monotonously offers entertainment as well as news/ information. In the morning, it broadcasts formal education (mathematics) and creativity programs (07.30-09.00), an introduction to a variety of national cultures (09.00-10.00), and sports (10.00-11.00). After midday news, it continues with a cultural program, a government's forum and education. A film only starts at 17.30 and consists of a rerun (Oshin). It broadcasts a soap opera for only 30 minutes from Monday to Friday (20.00-20.30). It would seem that children could safely watch the programs that TVRI offers. The only danger is that they get bored because the programs present no variation and are not entertaining as TVRI prioritizes information, education, and cultural development, as well as government issues. This station seems to have forgotten the entertainment aspect of its programs.

At close inspection, it becomes clear that RCTI (Rajawali Citra Televisi Indonesia) offers little variation because each day it features almost the same programs: news, gossip, music, a reality show, a soap opera, and a widescreen film.

a. The public especially favours RCTI's soap operas, which often receive high ratings. RCTI offers soap operas from Monday to Friday (a rerun of Si Doel anak sekolahan, Doel the schoolboy) lasting 1.5 hours (07.30-09.00); an afternoon soap opera from Monday to Friday for two hours (13.0015.00); daily early evening soap operas for four hours (18.00-22.00) with three different titles. In total, the station offers 7.5 hours of soap operas daily (which is almost $33 \%$ ).

b. Every soap opera has the same theme: love seen from many aspects, and the fight for wealth and power within the family. The luck of the protagonists often turns, for instance, poverty into extreme wealth because the protagonist happens to be his family's sole heir but has been lost for a long time, and other similar implausible plots. When the ratings of a soap opera drop, the conflict is sped up and the story is thus forced into becoming nonsensical.

c. RCTI (only) features children programs such as cartoons on Sundays from 07.30-09.00 (1.5 hours).

The competition between SCTV (Surya Citra Televisi) and RCTI is fierce, which is understandable as SCTV is an offshoot of RCTI. It broadcasts similar programs to those of RCTI and include news, gossip, music, reality shows, and soap operas.

a. SCTV starts airing its first independent soap opera early between 10.00 and 12.00 (two hours). The second independent soap opera is broadcast from 12.30 to 14.30 (two hours). From Monday to Friday it shows a serial soap opera from 18.00 to 23.00 (four titles in a five-hour marathon fashion). ${ }^{6}$

6 Buku Harian Baim (The Diary of Baim), Bayu Cinta Luna (Bayu Loves Luna), Cinta Fitri season 5 (Fitri's Love season 5), and Kesetiaan Cinta (The Trustiness of Love). 
On Saturday and Sunday it shows serial soap operas from 19.00 to 23.00 (three titles in a four-hour marathon fashion); and another independent soap opera from 23.00 to 00.30 (Thursday to Monday, 1.5 hours). Thus, SCTV airs soap operas for 10.5 hours (or almost half time).

b. The audience loves one soap opera (Cinta Fitri) so much that it has gone into its fifth season. This is a family soap opera in which many conflicts are developed. In it, a good character may turn bad and the other way around, while themes are developed and minor conflicts settled. The main conflict, however, has been maintained to this day. This soap opera continues to have the highest ratings.

c. SCTV does not feature any cartoons for children. If one wants to, one particular soap opera, Buku Harian Baim, may be seen as intended for children's audience as its main character is a child.

We should add here that the following chaotic stage programs are popular. Live stage programs featured by RCTI (Dahsyat, Awesome), ${ }^{7}$ SCTV (Inbox) ${ }^{8}$ and (Playlist), ${ }^{9}$ and Trans TV (Derings, The (Phone) Ringing $)^{10}$ are shot in and outside the studio and generally involve a teenager public. The teenagers can interact directly with the singers and show hosts. The question is whether their participation disturbs their school activities. These musical events generally last for about two hours, except Dahsyat Weekend (Awesome Weekend), which is aired from 7.30 to 11.00 on Sunday (rather than from $09.00-11.00$ as it is from Monday to Saturday). Inbox is aired daily for two hours from 07.30 to 09.30, Playlist from Monday to Friday from 15.00 to 16.00 hours, and Derings is aired from Monday to Friday for 1.5 hours from 09.30 to 11.00. These musical shows are interesting because they include hit lists. We may conclude here that RCTI, SCTV, and Trans TV (Televisi Transformasi Indonesia) strongly rely on musical shows.

Aside from life musical stage shows, infotainments are also interesting to highlight. They are aired daily and compete with criminal and political news shows (aired at breakfast time). RCTI has Go Spot (06.30-07.30); followed by SCTV with Was-was, Suspicious (06.30-07.30); Trans TV with Insert Pagi, Celebrities Investigation in the Morning (06.30-07.30); Trans 7 with I Gosip Pagi, I Gossip in the Morning (07.30-08.00, only from Monday to Friday). Subsequently, RCTI airs Silet, Razor blade, a razor-sharp infotainment (daily from 11.00-12.00); SCTV with Hot Shot (Friday to Sunday, 09.30-10.00) and Halo Selebritis, Hello Celebrities (Monday to Thursday, 09.30-10.00); Trans TV has Insert Siang, Celebrities Investigation at Noon (daily from 11.00-12.00); Trans 7 with I Gosip Siang (daily from 12.00-12.30). In late afternoons, the same shows are broadcasted by RCTI with Kabar-kabari, News Report (Monday to Thursday from 15.00-15.30) and Cek \& Ricek, Check and Recheck (Tuesday,

Hosted by Luna Maya, Raffi Ahmad, and Olga Saputra.

Hosted by Ivan Gunawan, Gading Martin, and Andhika Pratama.

Hosted by Cathy Sharon, Indra Bekti, and Dimas Beck.

10 Hosted by Sandra Dewi, Oki Lukman, Desta, and Agus Ringo. 
Wednesday, and Friday from 15.00-15.30); SCTV with Status Selebritis, The Status of Celebrities (daily from 14.30-15.00); Trans TV with Insert Sore, Celebrities Investigation in the Late Afternoon (Monday to Friday from 17.30-18.00, and Saturday and Sunday from 16.30-17.00); while Trans 7 airs I Gossip News (daily from 17.00-17.30). Other stations that almost on a daily basis also air infotainments are Global TV with Obsesi (Monday to Friday from 10.00 - 10.30); TVOne with Expose (Monday to Friday from 13.30-14.00); Indosiar with Kiss Pagi, Stories about Celebrities in the Morning (Friday, 07.00-08.30) and Kiss Sore, Stories about Celebrities in the late afternoon (Monday, 14.30-15.30, Thursday from 15.00-15.30 and Friday from 14.30-15.00 after Intan: Infotainment Anak, Infotainment for Kids); TPI (Televisi Pendidikan Indonesia) with Go Show 2 (daily from 14.30-15.00); and ANTV (Andalas Televisi) with Espresso (Monday to Friday 08.30-09.30 and Saturday-Sunday from 10.00-11.00). The obvious conclusion is that on Indonesian television as represented by RCTI, SCTV, Trans TV, Trans 7, Global TV, TVOne, Indosiar, TPI, and ANTV, there is no day without infotainment, and thus there is always gossip and gleeful peeking into other people's problems. ${ }^{11}$

ANTV is one of the stations that offer a balance in the shows it broadcasts. There are news shows, sports, children's films/shows, gossip, reality shows, quizzes, adventure, comedy, and DRTV (Direct Response Televisi) advertisements (special program). ${ }^{12}$

TPI (Televisi Pendidikan Indonesia, Indonesian Educational Television) which, as its name indicates, initially started as an educational station currently no longer predominantly concentrates on the educational side. The shows for children vary from Tom and Jerry cartoons, Upin \& Ipin cartoons from Malaysia, children soap operas and fantasy tales. ${ }^{13}$ Nowadays, Upin $\mathcal{E}$ Ipin are among the most popular shows in Indonesia..$^{14} \mathrm{TPI}$ strongly supports dangdut music and often organizes arenas to discover talented dangdut singers such as KDI (Indonesia Dangdut Contest) ${ }^{15}$ and Dangdut Mania Dadakan, Instant Dangdut Maniac. ${ }^{16}$

Indosiar also often airs soap operas. They resemble Indian films known as telenovela. They are fantastic and may include, for instance, a child born with three eyes and other peculiar features. It broadcasts soap operas from 07.30

11 See Riris K. Sarumpaet, "Realitas Buatan vs Realitas Impian", National Scholarly Meeting X Faculty of Graduate Studies Unpad, 20 September 2005.

${ }_{12}$ The following children programs should be mentioned: All new Popeye, Conch bay, Pororo the little penguin, Armor heroes, Sargeant Keroro, Panji sang Penakluk (Panji the Conqueror), and Anak Pemberani (The Brave Kid).

13 Kenapa ya? (Why?), Kera Sakti 1 (The Magic Ape 1), and Si Mamat Anak Pasar Jangkrik (Mamat, the Boy from Cricket Market).

14 This may be seen from the development of how children want to identify and imitate their idols and the franchise business in Indonesia from shirts sporting Upin and Ipin prints and Upin and Ipin dolls. Small children love to have them.

15 Now in its fifth or sixth episode.

16 Participants for these dangdut contests originate from general society and are audited on stage during real time featured shows. Tuan Takur presides over the jury who decides whether a contestant will continue to the next level or not. 
to 11.30 and 18.00-20.00/19.00-22.00, which amount to six to seven hours. Indosiar is also famous for showing Korean films or films from other Asian countries such as The Great Queen Soendoek.

Metro TV is mainly concerned with talk shows and has no programs for children whatsoever.

Trans 7 resembles Trans TV as it falls under the flag of the same enterprise. It offers a varied and balanced program and has various shows for children and adventurous stories. The soap operas it airs are also varied and tend to be comedies like OKB (Orang Kaya Baru) and Opera Van Java (OVJ), which everybody from children to adults loves to watch. It is staged to resemble a wayang puppet performance with a puppeteer who starts the prologue to the story accompanied by two female singers (pesinden). The characters include Parto (puppeteer), Sule, Azis Gagap, Andre Taulani, Nunung, and guest stars. It sometimes has slapstick scenes containing exchanging blows with objects made of polystyrene foam. ${ }^{17}$ People wait for this show because there are lively and funny scenes..$^{18} \mathrm{OVJ}$ offers all kinds of genres ranging from fairy tales, legends to daily lives and recent events. ${ }^{19}$ This station has a reliable talk show entitled Bukan empat mata, presented by Tukul Arwana.

Global TV is probably the TV station that favours children most. Starting from 05.00 to 10.00 , it features cartoons for children and continues this in the late afternoon and early evening from 17.00 to 19.00 , and thus has a total of seven hours devoted to programs for children. On Sunday, it even has a more varied program with as many as thirteen different programs. ${ }^{20}$

TVOne often features the hottest news items. ${ }^{21}$ Most of the programs it airs consist of news shows, talk shows, dialogues, documentary films and sports. TVOne has no children programs and airs no musical shows or soap operas.

Trans TV is very popular because it dares to feature innovations. The programs it airs consist of news shows, gossip, travel adventures, cooking shows, reality shows, quizzes, soap operas, and music. The soap operas it airs are comical and include Suami-suami Takut Istri (Husbands Afraid of Wives), Kejar Tayang (Stripping, running the series), and Angel's Diary (shortened to last only one and half-one hour). Its reality shows feature stories popular in society, such as Termehek-mehek (Cry and Sob), Orang Ketiga (The Third Person), and Realigi. ${ }^{22}$ The station has no special shows for children.

17 Usually, there is an announcement that the material used for the objects can cause no bodily harm.

18 It may very well be that people are bored with the endless and chaotic soap operas that fail to satisfy their urgent and critical needs for emotional release.

19 For instance, the story of singer Krisdayanti and Anang's divorce was taken up as story material by changing the names of the original characters.

20 Tak and The Power, Of Juju, Dora The Explorer, Spongebob Squarepants, Avatar, Inuyasha, Amel Cemal Cemil, Boogie Woogie, Ayahku Hebat (My Dad is Cool), Lensa Ajaib (The Magical Lens), Little Heroes 3, Naruto, and Naruto The Movie 1.

${ }_{21}$ It featured direct footing of the entire process of the rounding up of the Indonesian terrorists.

22 The stories center around the topic of the search for lost relatives, spying on persons for whatever reasons, and other issues in society. 
It is thus clear that in general television programs are made for adults: news, talk shows, gossip, soap operas, and others. We only have to look at the life stage musical shows, infotainments, other programs and especially marathon soap operas, which are aired daily during prime time, to see that children watch and imitate them. However, does this mean that the directors think that shows for adults but aired when children also watch them on their parents' laps should be considered to have been made for and are means of entertainment for children? No matter how much effort is made to produce diverse and quality programs for children to watch, considering reruns, old stories and other "educational spirits", they remain insufficient for the urgent need for quality and diverse programs for the development of children. Knowing this and in light of the importance of proper programs for children's entertainment and development, below I will provide some examples of programs currently aired. The four stations have been chosen based on the programs they provide especially for children. This assessment will pay attention to the contents of the programs and the considerations that have been made especially for a juvenile audience.

\section{TVRI, SCTV, TRANS 7, RCTI: DIDACTIC, SUPPLEMENTARY, LOYAL, AND DYSFUNCTIONAL}

We need to discuss the children programs TVRI offers since it is the first Indonesian television station. Above it has already been stated that its programs are monotonous and unattractive. The morning programs for children reveal that TVRI is uninterested in its juvenile viewers who generally are, and should be at school.

First, we will take as an example the ten-minute Budi dan Kerti program entitled Afif ingin jadi artis (Afif wants to be an artist). In the first scene, three children are playing soccer. One of them, Afif, sees an announcement of a theatre studio that might turn him into an artist. This appeals to Afif and he stops playing soccer. In the next scene, two dolls appear, Budi (male) and Kerti (female), and talk about Budi's art. The character of the uncle (played by the artist David Khalik) enters the stage, talks to Budi, and gives him some information: "If you want to be an artist, there are certain conditions. You may not be conceited and have to be friendly and love your family". In the third scene, Afif is in the theatre studio and with his friends he studies how to perform while the roles are being divided. Afif is assigned the role of an extra. He does not like this, and he becomes upset because he is disappointed with the studio's leadership. Next, Budi, who is an artist, is busy reading, but he is interrupted all the time by fans who want to ask for his autograph. He also gets upset. Kerti comes in and Budi accuses her of being one of the people who interrupt him. The uncle comes and intervenes. Next, Afif comes in and loudly complains. The uncle asks him what the problem is. Afif tells him about his wish to become an artist in order to be famous and rich. However, he is disappointed because in the theatre he only gets the role of an extra. Kerti asks what an extra is. Uncle explains the roles of extras, and that they 
are chosen because of the characters they are required to play. Uncle also explains that there are risks in becoming famous as Budi just experienced. He said that actually one does not have to become an artist in order to be famous as one can also become well known by doing good deeds such as told in the following story: "There was a story teller who told a story about the Prophet Muhammad, who was very famous because of his Al Amin character, thus all the Quraish could trust him to settle their problems".

The title Budi dan Kerti (Budi and Kerti, from budi pekerti "manners") directly refers to the important connotation of "good conduct" and - as may be imagined - also directly to the fact that children immediately know that they are being lectured. As the various scenes I discussed above show, it is very clear that the program contains lessons. It states that one does not have to become an artist in order to be famous and that the important thing is to do well in emulating Prophet Muhammad. The character of the uncle, who represents adult people in the scene above, leaves no possibility or alternative for Afif to become rich. The process of performing in the theatre is never related. In this play, theatre is only used as a means to deliver the message that children should do well. There is no action typically done by children or that which involves them for their entertainment. This is nothing more than "good conduct" lessons delivered by adults from the stage and in the wrong way. ${ }^{23}$

Second, SCTV airs Buku Harian Baim at 18.00 hours and the main character is a sick child who is "sentenced to death" because he can no longer be cured. It is apparently used as a means to show adult problems. While waiting for him to die, which is suspended all the time, and the moment never seems to come, Baim functions as a kind of "advisor" exhorting people to act well. ${ }^{24}$ It is, therefore, no wonder that the dialogue is extremely artificial, and Baim has to suffer so much and has to suffer his antagonists' much too contrasting, rude, and dramatic actions. Even though Baim's friends Izam and Abel and the way they interact - for instance, when they go out to look for heaven on their bicycles, or when Baim talks to his stuffed bear, or when his father talks to the stars, are touching and make sense, the children remain sketchy and in fact are only used as objects to be ignored. ${ }^{25}$ These shows mainly revolve around the problems of adults and how rude, mean, full of intrigues and quarrelsome adults are, and therefore should not be emulated.

Third, Trans 7 airs Bocah Petualang (The Adventurous Boy) daily at 12.30. We should salute the freshness of the ideas and the possibilities it offers for the audience to watch the Indonesian panorama. It also shows that children

23 During the research on these programs, young mothers immediately said when interviewed that their children no longer watched TVRI. In their views, their children find these programs uninteresting. The old show Oshin is also no longer interesting compared to programs aired by other stations, which are much more novel and varied.

24 This is also peculiar. How can one make efforts to pay attention to children while the means has turned into lessons for adults? Do these adults not realize and understand that children are children? Where does this Baim get his instant wisdom from?

${ }_{25}$ There is a scene where Baim's father, who yearns for his son, talks to the stars as if Baim were there as one of the stars. 
are freer to be themselves. In general, this program introduces Indonesian culture be it food, customs, ways of agriculture, calling eels in the rice paddies, travelling in a pedicab and so on. There is always some element of "preaching". It teaches how to obtain the relentless spirit needed in order to get money, to excuse one another and not to harbour spite, to work hard, to be industrious and to protect the environment and a host of other values. In short, this show smells didactical agenda.

We may say that these shows deceive the audience. Why? They claim that the boy is adventurous, but it never becomes clear what these adventures are, and what the desires behind them are because it is ever so clear that everything has been arranged by the text writers, in short, by adults. There is no impression whatsoever that inspires us that these kids are adventurers. Short scenes have to deliver as much as possible the importance of being "industrious", for example, or how to protect the environment, and the programs always display a spirit of didacticism. One never gets an impression of development or of a delicate but profound process behind the type of preferred behaviour the program offers to the public. Because of this, the end of the story is always easy to guess. This program may be compared to a "travel" show that shows interesting places and objects in the regions visited by the show's host. This "travel" show would be acceptable because we know it will take us to new areas. But how about Bocah Petualang? It wants to represent children and their interests, but this idea is always lost by the adults' insatiable desire to preach. Moreover, in this show, adults should carefully reckon with some events. For instance, during one particular episode, we get the impression that adults are lazy, hot-tempered, are feared by children, annoying to be in power etcetera. It is evident in this show that adults are not friendly towards children. They only control things, give advice, and - this is very evident - are oblivious towards the need for children to play. This story, moreover, often contravenes logic because it fails to provide sufficient reasons or explanations during the travels in time and place. It may happen that all of a sudden, the children arrive at a certain place, for instance in Yogyakarta, but nowhere is explained how they arrive where they need to be and with whom, which impinge on the stories' credibility. Hygiene, for instance, which is extremely important, is never touched upon. The program is mainly concerned with giving advice, with obedience, and not on exemplary actions that may be emulated.

Fourth, Laptop Si Unyil (Unyil's Laptop), which is aired right after Bocah Petualang, suffers the same problems. This program also features illumination and information to make children (feel) smart and involved. Thus, children borrow a laptop to show that they are up to date, but in fact, it is only a means to convince the audience that there is something mysterious there and that the laptop can explain it and give directions. If feels as if this show has borrowed the idea of a Private Eye in Western films who is similarly guided by a computer screen. This is also an adult scenario where those in charge direct the children so that they may become smart. Nothing in this show is geared towards children. The ways these children talk and behave resemble adults, which is very annoying. Just look at how they ask questions 
in a certain manner, the way they laugh and try to convince someone which actually leaves behind the impression that they are stupid. In one episode, the children are making a stove that uses a certain burner. ${ }^{26}$ When Unyil explains how the stove works, which - at that moment - is already alight, he has his head very close to the fire. ${ }^{27}$ How can one explain fire to a child? Is it not so that by having Unyil's head so close to the fire that this may emphasize in the eyes of the children watching that fire is not hot and dangerous?

Another episode has a similar problem where Javanese snacks (getuk lindri) are made. Technical terms that need explanation pass by much too fast. This also shows that this program only sought to provide one-sided explanations, which viewers apparently do not need to understand. In addition, here the issue of sanitation and hygiene are overlooked since the children pick up the snacks without wearing gloves and, moreover, the snacks have just been taken out of the oven and must certainly be very hot. The idea that his friends always abandon Unyil gives the impression that he has difficulties making friends. In addition, why does Unyil have to scratch his head all the time for no reason? Is he really always itching? Are they, for instance, in a garden full of mosquitoes? Or is he allergic to something? Apparently, adults are so busy with their own agenda that they forget that it is important to see if there may be other hidden agendas in their schemes. Again, this program is much too educational, and lessons are provided from the high stage of adults.

Fifth, since children may potentially watch every program on television, it is interesting and even necessary to pay attention to Kemilau Cinta Kamila (The Glow of Kamila's Love) aired by RCTI. The title indicates that Kamila is a character whose love is strong. During the episode of 8 May 2010, we learned that her pregnancy is problematical. She is pregnant out of wedlock but will marry Dr Fadil, whom we have never seen before in the hospital or taking care of patients. Wearing a white coat, he only sits behind his desk. In this episode, Kamila decides to go home to Fadil's place rather than to the house of Mrs. Tini, her grandmother who hates her because she is pregnant but not married. Apparently, Kamila's grandmother has an adult son whom she strongly protects. It is not difficult to guess that Mrs. Tini has a problem with Harris, her son, because she does not want him to know that Kamila is his daughter. Harris is dating Mrs. Laras, whom Kamila calls "mother", even though she is not her real mother. The situation becomes even more complicated because Harris buys a baby's outfit for Kamila. Meanwhile, Fadil's mother cannot stand Harris and even has him thrown out of the hospital. Kamila has only been at Fadil's place for one single day when problems arise. Indi hears that Kamila's baby is not Fadil's child. Kamila cries all the time and she strokes her belly. The next morning, before Fadil leaves for work, his mother asks Kamila to "get used to kiss Fadil's hand when he is about to leave", his father adds "as a token of dedication of the wife towards her husband".

26 I have been unable to find notes on the exact date and title of this episode.

27 This, of course, indicates that the director was unaware of the surroundings and the impact on the children who watched this episode. 
The mother is very dominant in this family, quick-tempered and at the same time unconfidence. Fadil's father, on the other hand, only acts to cheer things up. Laras also dominates Harris. This is even more so with Mrs. Tini, who orders her son around and asks him to marry fast so that his room can be cleaned out. This woman even falls ill after only having been bitten by a mosquito. Her health turns into a threat and a means to incapacitate Harris. What is really troublesome is that Harris is extremely obedient towards his mother. It even becomes clear in the episode aired on 9 May 2010 that she tears up a letter Harris is reading because she is furious that Harris almost learns that Kamila is her own daughter. She then proceeds to Fadil's house to have a word with Kamila and to demand that she quits harassing Harris.

When we see all this, we truly wonder about the urgency of the actions of Mrs. Tini, who is an extremely possessive and powerful woman. When Fadil forbids her to see Kamila because he is afraid that Kamila's condition might deteriorate and because he fears that his baby may endure stress, Mrs. Tini, who is already old, says that as far as she is concerned, Kamila's baby "is no concern of mine". She even stresses that Fadil should not protect Kamila as she is with child without being married. Edo (anyone should be confused by now!) himself is also angry because he wants to have proof that he is Kamila's baby's father. Kamila opts to follow Fadil. Edo's mother is also normal strange character as she refuses to be parted with her son and even goes as far as not to allow him to go out for work. She thinks that Edo's salary is a joke, and she even brags that she can pay that sum of money herself. On the other hand, there is Alena (Mrs. Tini's granddaughter?) who is forced to part with her date, Taufan, because he is crippled. Alena, who is a career woman, cannot contain herself and acts unprofessionally. While working, she suddenly exclaims "I want to see Taufan, I want to see Taufan", and then closes her desk and leaves. Without any transition whatsoever, she suddenly arrives in front of Taufan's house. This story also becomes increasingly confusing as Taufan denies her entry to his house.

This longwinded film is full of black and white characters having black and white problems. It is extremely easy to follow, and it is not hard to predict what will happen next. The characters act as puppets, have no souls, let alone the guts to become resourceful agents of socialization and indoctrination. Just look at the way Mrs. Tini forces Harris to forget Kamila. It is very strange to watch a good-looking professional man having no opinion of his own. He even has to ask the help of others to be able to visit his own child. He then weeps like all other female actors in the story. It is also difficult to explain why Mrs. Tini wants to have nothing to do with Kamila. How might we explain this kind of attitude to children? Is she a fraud? Or, does she have no pity?

Apart from featuring types that defy the audience's common sense, absurdity becomes the shows' hallmark. In all situations, the actresses are completely decked out with false eyelashes and full mascara so that they look like terrifying Venuses. Moreover, when as couples, like man and wife, they discuss some important subject in an intimate situation, there is no sense of 
intimacy at all. In this idiotic play, couples are cold and distant. Their body language is one of restraint, and they do not show it when they are falling in love. They have no affection but can only talk and blabber. The women are portrayed as fragile and armed with tears. Pregnancy is depicted as a terrifying event, while the only use of women is to mop the floor and be loyal to their spouses. Thus, this show promotes and teaches that there should be fidelity and obedience rather than love and compassion

It would seem that these shows perceives the viewers as having no brain or any other cognitive sophistication, so many problems are explained time and again in dialogues or in the narration or even, when necessary, in monologue flashbacks. The story becomes excruciatingly boring. When Taufan holds Kamila's hands, his future sister-in-law, Indi, who apparently never has to go to work appears and takes their picture. The photo is sent by SMS to Alena. Taufan has his head in bandage - we never learn why it is never taken off, renewed or his wound is never cleaned. The plots are saddening and deceive the viewers with their endless illogical sequences. The shows give children the impression that no adult ever needs to be taken as a role model. Most events make no sense at all, are over the top, and have never been researched. For instance, since when do invited guests at a photographic exhibition in Jakarta wear a coat in the evening? It all looks amateurish. Moreover, the show does not involve any child! This show is only about adults' foibles. This and other shows imply that on Indonesian television no family is unharmed. What is shown as models on Indonesian television stations are dysfunctional families.

Sixth, the soap opera Safa dan Marwah (Safa and Marwah) is aired after Kemilau Cinta Kamila. This film is the most inundated with tears. Safa cries incessantly because of her lover's death. In episode 220, she is so sad so that she falls asleep on Ilham's grave. In the bedroom on the second floor of their house, we see his father, who weeps over Ilham's photos and who talks and rambles while he is crying. Marwah looks puzzled and then asks Farid to look for Safa. We have to remember that Farid is blind. In the dead of night, he visits Ilham's grave accompanied by his trendy driver where he finds Safa and carries her back. Then, without any explanation, Farid has an eye operation and he does a lot of praying and hoping. All at once, the operation is over and one would wonder if a coronary operation to the eye is ever that straightforward. How about the waiting process and finding a proper donor? His doctor is also completely unconvincing and he even lets himself be bossed around by his patient. Is this perhaps an irony? There is a character named Eva who is money-hungry and whom Farid's mother uses to keep Safa away from Marwah. Apparently, Safa who, while being sad, is able to express herself at times or she reads a letter (we hear her voice and witness her tears fall) and does nothing but weep. Knowing that the story flows as so desired by the audience, it is still not clear why everything is the way it is. 


\section{READING OPERA VAN JAVA AND ISLAM KTP28}

After having discussed the programs on Indonesian television in general and the programs for children at four TV channels, we will now proceed to two shows that are in demand and well liked by adults and children: Opera van Java and Islam KTP (Islam on ID-Card). My students found that children like both OVJ and Islam KTP. Faithfully, they wait the hours when these shows are aired. They wait for these shows because of their liveliness, the teasing and, of course, the extra information they may digest from watching them. They like OVJ because it is "funny, lively, and cool", while they enjoy Islam KTP because it "teaches the true religion" and features "interesting characters". Because they like these shows, children abandon their homework and even postpone going to bed in order to watch them. In a relaxed, warm, and cheerful atmosphere, they watch the shows with their household helps, grandparents and/or their parents.

This part of the article will report on the findings gathered during fieldwork.

\section{HILARIOUS AND POPULAR OVJ}

This Trans 7 comedy is aired from Monday to Friday from $20.00-22.00$ and may be said to be much in demand and highly appealing. ${ }^{29}$ This modern version of a "Wayang Orang performance" indeed provides an old theatrical style with a new face, new colours and in novel ways. With female singers (pesinden) in the background (singing pop songs!) and advertisements during the breaks and clues to where the story will lead, the whole show is accompanied by traditional Javanese music. The dalang (narrator) relates the story, and the wayang characters act it out by making their own interpretations and using their own imagination in an atmosphere of total improvisation. It is, therefore, not surprising that people await this hilarious show. Misunderstanding, miscalculation, wrong actions and wrong pronunciation, coupled with the dalang's bewilderment that his instructions are questioned and not acted upon adds to its source of merriment. The dalang's presence also adds to its banter.

The show's main objective is to make the spectators laugh. This may be concluded from the sentence that marks its spirit: "There is a mountain over there, there is a mountain over here, and in the middle is the island of Java. The actors are confused and so is the dalang. 'The main thing is to make people

28 This part discusses the outcomes of discussions I had with of my students in the course Pengkajian Cerita Anak 2010/2011 (Study on Children's Literature 2010/2011). I would like to thank Ratna Djumala and all the students who, with much enthusiasm, fought against the "stupidity" and the poor behaviour of parents concerning the world of children shows in Indonesia. I would also like to express my gratitude to Siti Baroroh and the students of the Global Islamic School in Jl. Condet Raya 5, Kramat Jati, East Jakarta. Thanks also go to my fellow mothers and the fathers who voluntarily gave us their thoughts on the shows we were investigating.

${ }^{29}$ OVJ has twice received the Panasonic Gobel Awards in the category of "Favorite Comedy Program" in 2010 and 2011 (see http://id.wikipedia.org/wiki/Opera_Van_Java, accessed 12-12-2011). 
laugh.' We meet again in Opera van Java. Hurray!"We may thus say that by "engineering mistakes", this show strives to amuse and to make people forget their sorrows. Even though it is a kind of "wayang performance", it does not always enact a wayang story. It also exploits topical events, real stories, folk tales, ghost stories, international stories et cetera. With players like Parto Patrio (dalang), Nunung, Azis (Gagap), Andre Taulany, Sule and Desta acting as wayang characters, singers who take turn and guest stars chosen in line with the story, we should not be surprised to find episodes entitled "I love Indonesia", "Tragic love", "Uncoordinated small family", "Pastel kung fu", "Katot Kaca's birth", "The 11th January mystery", "Free companionship", "Village elections", "Romeo and Juliet", "Tegal, I am in love", "Infectious speech", "Yakuza", etcetera. As the elusive titles reveal, each show contains a socially relevant element.

\section{Fatso, stupid, and worthless}

The students found that children who watch OVJ tend to imitate the actors' behaviour of kicking, hitting, pushing, and screaming that they view in this show. ${ }^{30}$ They also found that these children loved using the "funny vocabulary" they hear from this show, such as "dower, $l u$ " (protruding lip), "dasar gendut" (fatso), "banci, lu" (queer), "bego, lu" (idiot), "dasar pesek" (flat nose), etcetera.

When interviewed, the children said that they "sometimes did not understand the story because from start to finish the actors were only making jokes". They did not really like it because "there is too much violence in it". They also found that "sexual innuendo" was used explicitly to draw laughter.

The pupils of the junior high Global Islamic School in East Jakarta said that they considered the show "full of unnecessary jokes and fun. It is easy to predict the plot [...] it is boring. The humour is 'dry' and not funny. Sule, who always becomes a looser, does not make sense". In short, they consider it "Unintelligent", "Wrongly made entertainment", "After a while, it becomes boring", "Over the top and not educational", and, worse still, "The stories and the titles don't match". However, we should add that they also said that the show is good way to "get rid of stress".

The students also found that the show was indeed made to draw laughter by often using foul language, hitting certain body parts, pushing until someone falls, and putting things into the mouth of others. They found much ridiculing, rude and painful teasing, making fun of bad luck and physical impediments. The show also features "improper" incidents such as wetting one's pants. It was also considered "sadistic" because it uses language like "Can't we just cut of his hand first so that he can't bother us", or "You'd better squat here and I will fall on your head".

The children's parents think the show is "worthless. It only has cheap loud laughter and teaches children to be wicked by pushing people and destroying 
things. The comedy does not sharpen the children's minds. There are no lessons in it, especially for children" ${ }^{31}$ The parents were mainly worried about the rude language and behaviour, the derision, extreme jokes, behaviour and sexual verbal innuendo, and the violence they found in OVJ. In short, for them it is an "adult show, end of story". They think that it has too much taboo and is not meant for children.

\section{The logic behind neglecting "entertainment"}

The findings revealed some interesting points. As in so much other research, this study also reveals that children easily enjoy and imitate shows and other spectacles they see on television. Especially because of the hilarious atmosphere with lots of laughter, in their daily life children easily take over the behaviour and words the cast uses during the shows. The students also found that children are not quite as uncritical as many adults think. This becomes evident from the way children respond when something in the shows is "taboo", what smells of "sex" and that some acts are violent. Junior High School children are even able to decide if they think shows are "dry", "don't make sense", "over the top and less educational". We should add that some of them consider OVJ as "helping to relieve stress". We may wonder if this should be considered as a positive indication of the swift maturity of these children or whether this is the outcome of our neglect and that of society in general as well as their parents, so they are forced to find their own ways to manage their complex lives in order to safeguard themselves. Even though some parents allow their children to watch it, we may say that most agree that $O V J$ is not a children's show.

As far as the stories go, some conclusions may be drawn from the input and comments made by the children, students and parents. Firstly, OVJ is not a strong show because it is weakly structured and not well made. Because it is only funny, no matter what topic is thrown at the jesters, they will always turn it into a story that goes all over the place, with multiple levels, overlaps and digressions. We even found instances of titles having no relation whatsoever with the content of the story. Also, in the process of narrating the story, it is inconceivable that children understand all the references, allusions, and hints both in word plays, events, protagonists, numbers et cetera - that make many people laugh. In fact, the children do not really understand the stories, but they like to laugh with the laughter there is, with the jesters they know from advertisements, together with their families sitting next to them who stop working to enjoy the shows. Children often have difficulties in drawing conclusions from the episodes, they do not understand the plots and thus fail to capture what the contents, themes, or messages actually are.

Secondly, the dialogue and substance of the stories and how they are conveyed all evolve around jokes and banter, discussions, alternating laughter, pushing each other, throwing insults at one another, making fun of each other

31 These parents are 30 years or older, work and are educated up to S-1 (bachelor) degree, and they have children who watched television. 
and, if necessary, humiliation. The question arises is what impression these ludicrous shows are supposed to leave behind since no conclusions can be drawn, while the essence and the message of the shows cannot be deciphered? A growing child needs input from everything it watches, and if what he/ she sees or reads is "banal", we can imagine its negative impact during the period of internalization of the stories and the inherent virtues contained in the stories. Thirdly, children have no problem to imitate everything that is being demonstrated in this show, including the artificiality, the hitting, kicking, and especially the "sexual innuendo", and the exploitation of others. Children will understand the ridiculing of the misfortunes and all other acts of violence as something logical and, (thus) because acted out by their favourite stars, they feel they have to imitate them. These three conclusions show that, when children endlessly watch the persistent behaviour displayed in this show by grownups who ignore their presence, adults and society in general consciously neglect them. Society neglects their presence, their uniqueness and their needs.

\section{ISLAM KTP, WHICH IS "NOT JUST ENTERTAINMENT"}

Islam KTP is a comical-religious soap opera aired by SCTV from Monday to Friday from 18.00 to 21.30 hours. It is produced by Multivision Plus, and the cast includes Idrus Madani, Reza Aditya, Aiman Ricky, Ramdhani Qubil, Tubagus Indra Zulfarmansyah. As we can see from the title, this religious comedy is a "means for religious and moral education and 'not just' entertainment". Some of the titles include Ahyat Bojonegoro, Sampeyan Muslim (Are you Muslim?), and Taklim tentang hati (Qalbu) (Recitation about the heart).

Islam KTP's main theme immediately becomes clear from the opening and closing song "Tobat maksiat", which was written by Wali. Its lyrics are as follows:

Dengarlah hai sobat, saat kau maksiat, dan kau bayangkan ajal mendekat, apa akan kau buat.

Kau tak 'kan selamat, pasti diri muhabis dan tamat.

Bukan ku sok taat, sebelum terlambat.

Ayo sama-sama kita tobat, dunia sesat.

Awas kau tersesat, ingatlah masih ada akhirat.

Ingat mati, ingat sakit, ingatlah saat kau sulit.

Ingat ingat hidup cuma satu kali.

‥

Pandanglah kesana, lihat yang di sana.

Mereka yang terbaring di tanah, bukankah mereka

pernah hidup juga, kita pun kan menyusul ke sana.

Listen up, my friend. The moment you act immorally, and you think that your life's end is due, what will you do?

You will not be safe and you will surely be over and finished. 
It is not as if I pretend to be loyal, before it is too late.

Come, let us repent together, the world has gone astray.

Take heed not to stray from the right path, remember the Day of Judgment is still to come.

Keep in mind that you will die, remember when you were ill, and remember that you went through hard times.

Remember that you live only once.

Look there, see what is there.

They, who lie in the ground, have they also not.

Once been alive, we too will follow them there.

Considering that the show is a "means of religious and moral education and not just entertainment", and in connection with our research on children shows, many issues and questions come up. The first, pressing issue is that the theme of the show can be guessed from the introductory song. Whatever the explanation is, this show is clearly not for kids. It is inconceivable that growing children should be fed with human conflicts adults are involved in connection with their faith. How can we speak of repentance to children who still have to learn to walk? And how can we explain the meaning and essence of immorality, deviations, end of life, the Day of Judgment to children who prefer to run around in the garden? Therefore, we will approach this show by first paying attention to what respondents had to say and subsequently discuss this. At the end, we will try to summarize this show as a story evolving around people.

\section{Smelly tadpole, rubbish, and insulting}

The mission of this soap opera is clear. It intends to exhort people that they should not just be "nominal Muslims" and not only adherents of Islam because they are registered as such, but that their daily lives should truly reflect the teachings of Islam. The children had no problem to capture the religious instructions of this show, and they commented like "Tebe gives advice that in fact [...] are given by Islamic specialists (ulama)". They also point out that the main characters, including Tebe, "ask money for the information they provide". For instance, "Tebe's father said, when I have money, I am out of here [...]!!". They are concerned with the characters they should emulate, such as the favourite character of the neighbourhood chief who "never works and only says 'why, why' all the time" or the favourite character of the miser Bang Madid, who "keeps track of his donations". Bang Madid time and again calls people bahlul (buffoon), as well as denigrates Tebe as a "smelly tadpole" and "poor bastard".

Pupils of the Junior High School Global Islamic School in East Jakarta said that this show "teaches Islam (using comedy), but that it uses foul language". They said that they "did not like it because they cannot understand the plot and that the characters say things they were not allowed to hear and scenes 
they were not supposed to watch". They also stated, "There are many funny and broken words", and "The characters use many words and babblings that are unfit to repeat". One of them stated that the show is actually "funny, but the stories are mediocre, uninteresting, flat, and unchallenging. I don't like it". Someone else said "It is good to watch because it has Islamic teaching in it. Only, the characters that should act like role models themselves deviate from what they teach". We should also pay attention to the fact that "The words the characters use are not very educational, but the show does have Islamic teaching". Some other students said that the show "uses bad language", making it "less attractive", and more than one of them admitted that the show "offers Islamic guidance we should take at heart" and "many Islamic teachings. The bad roles of the characters make us realize that people like that exist in our society".

On the other hand, the pupils talk about the leading figures in the soap that have clearly distinguished characteristics as they are "angry person", "jealous person", or "charity counters". Because of the way they appear in the soap, they clash with the teachings they deliver. Moreover, because they are a little bit older, and the students were also able to note that the show was "too flat as everything was only on the surface".

Almost all parents agree that the show is unfit for children. For instance, they said categorically "Many characters sport Muslim attire but their language is rude, they scream and shout wide eyed, and they curse and humiliate each other. They also tend to trivialize and the show does more harm than good". Others say "Very bad. The language and the jokes [are awful], and the children only have to learn how to answer in their own favour". Another parent added "it is not for children's consumption, it is worthless for children's education". Yet, someone else said, "It is actually good, there are religious teachings here and there, but there are indeed negative scenes, especially those showing children who ask for money and then run off".

\section{The logic of the disregarding "not just entertainment"}

Field observations revealed that the children who were interviewed had a rather good idea of what is meant by Islam. The way they reacted to this show varied, of course, but although they considered the stories "hard to follow" and thus not very attractive, they were aware that "Islamic teachings" were at stake. They also understood that the show focuses on religion and thus "has" to provide models. For this reason, they protested against the presence of the main character who did not provide proper examples. Apparently, the children also know that the soap operas they watched should provide them with knowledge about life. On the other hand, these Junior High School children were more outspoken and were clearly able to point at improper language, "expressions we should not hear", "behaviour that does not accord with the teachings", et cetera. The students also looked critically at the figures with clear-cut characters, which they concluded to be "jealous person", "alms counter", "thief", and so forth. Parents clearly denounced the show as being 
"worthless for the education of children".

From what has been said above, it is clear that despite the show's claim to be a "means for religious and moral education, and not mere entertainment" nothing the respondents said agreed with the soap's promise. Looking at the theme, the show is indeed not intended for children, but they watched it anyway, together with the rest of their families, and thus some points need to be highlighted. First, the show is not very interesting because it lasts far too long, the story is unclear, there is no drama because it is shot in snapshot fashion, and the characters are social types. Structurally, the show is weak. Secondly, because of the way the story is managed, it uses one-dimensional characters such as a helpless beautiful mother, a thief, an alms-counting husband, a person who prays, the wife of the jealous man, an advisor, a paramilitary defence officer, an extraordinary child, etcetera, which make the show un educational. This means that, seen from its substance, characters, events, and the instructions children should internalize, the program is unfit for them. Thirdly, the stories are considered artificial, foreign, and stigmatizing, and thus contravene the essentials of child education, the more so with the variety of "negative" behaviour it displays that children may easily imitate. When adults allow children to continue watching this show - which is not meant for them -this is another proof of neglect.

\section{FINAL REMARKS}

While researching these shows, children were placed in the centre of attention. We are convinced that growing children need special attention because they have specific needs. They are developing and, therefore, requiring adult's help in order to maximize their motoric, cognitive, psychological, social, and cultural growths. After we studied the programs presented by TVRI, RCTI, SCTV, ANTV, TPI, Indosiar, Metro TV, Trans TV, Global TV, TVOne, and Trans 7 that dominate Indonesian television, we conclude that they are made for adult audience. There are special children programs, but they are insufficiently entertaining and uninteresting. Also, because these shows have to compete with the large appeal of other programs for instance music and talk shows, children look for shows that are not made for them. We may say that, despite all efforts, we found that children are clearly considered unimportant.

We have tried to study six shows on television. TVRI's Budi dan Kerti is far too educational. In SCTV's Buku Harian Baim, children are mere instruments and sponged of persons to deal with adult problems. Trans TV's Bocah Petualang cheats its audience because it gives the impression of presenting a child having adventures, whereas in fact it only wants to teach children. Trans TV's other show, Laptop si Unyil, has the same defects. Kemilau Cinta Kamila and Safa dan Marwah aired by RCTI are not made for children, even though children watch them. The first is only educational and teaches how to be obedient and loyal. The second is somewhat different. It is still educational, but it mostly presents dysfunctional families, which do not provide good examples. They all clearly show that, for them, children are irrelevant. 
We looked at Opera van Java and Islam KTP because - bizarrely enough children like them. Children watch both shows with other family members, and they cannot wait for the shows to start and they enjoy them. It seems like both shows teach them something. Our survey reveals that both shows are considered bad and unfit for children. Nevertheless, the fact is that children enjoy them so much indicates that there is no doubt that they imitate the behaviour portrayed in both shows they watch against all advice. The shows are aired during the time children should study, which reveals that children's need have not been taken into consideration. The jokes made in these shows also reveal how lax and biased the values being delivered are. All this is testament to the fact that adults do not think children count. Their presence is of no concern to them. Different from Hundt (1995), parents, educators, television station owners and even the Indonesian government are insensitive to the special world of children. Our research shows that Indonesian TV shows intentionally neglect children.

The conclusion is that Indonesian children watch everything that is not actually made for them. Thus, they are fed with ideas that slowly but surely will harm their bodies and souls. In this way, Indonesian adults and TV stations intentionally create a future obedient, devoted and "dysfunctional" Indonesian people.

\section{REFERENCES}

Adams, Paul C. 1992. "Television as gathering place", Annals of the Association of American Geographers 82-1: 117-135.

Anderson, Daniel R., Aletha C. Huston, Kelly L. Schmitt, Deborah L. Linebarger, John C. Wright, and Reed Larson. 2001. Early childhood television viewing and adolescent behavior: the recontact study. Boston, MA: Blackwell. [Monographs of the Society for Research in Child Development Vol. 66, No. 1: i-viii+1-154; http://www.jstor.org/stable/3181552, accessed 30 -3-2012.]

Berry, Gordon L. and Joy Keiko Asamen. 1993. Children and television: Images in a changing sociocultural world. Newbury Park, CA: Sage.

Brown, Ray. 1976. Children and television. Beverly Hills, CA: Sage.

Chen, Milton. 1996. Anak-anak dan televise; Buku panduan orangtua mendampingi anak-anak menonton TV. Jakarta: Gramedia Pustaka Utama.

Clarke, Angela Teresa and Beth Kurtz-Costez. 1997. "Television viewing, educational quality of the home environment, and school readiness", The Journal of Educational Research Vol. 90 No. 5 (May-June): 279-285. [Http://www.jstor.org/stable/27542105, accessed 27-2-2012.]

Cline, Victor B., Roger G. Croft, and Steven Courrier. 1973. “Desensitization of children to television violence", Journal of Personality and Social Psychology Vol. 27 No. 3: 360-365.

Fabes, Richard A., Patricia Wilson, and F. Scott Christopher. 1989. "A time to reexamine the role of television in family life", Family Relations Vol. 38 No. 3 (July): 337341. [Http:/ / www.jstor.org/stable/585062, accessed 30-3-2012.]

Fiske, John and John Hartley. 1978. Reading television. London: Methuen. 
Gunter, Barrie and Jill McAleer. 1997. Children and television. Second Edition. New York: Routledge. [First edition 1995.]

Hundt, Reed E. 1995. "Serving kids and the community: do we want TV to help or hurt children?", Vital Speeches of the Day (New York, 1 September) Vol. 61 Issue 22: 674.

Kitley, Philip. 2001. Konstruksi budaya bangsa di layar kaca. Jakarta: Lembaga Studi Pers dan Pembangunan, Institut Studi Arus Informasi, and PT Media Lintas Inti Nusantara.

Melody, William. 1973. Children's television; The economics of exploitation. New Haven, CT: Yale University Press.

Nodelman, Perry and Mavis Reimer. 2003. "The world of children's TV", in: Perry Nodelman and Mavis Reimer, The pleasures of children's literature, pp. 139-142. Boston, MA: Allyn and Bacon.

Nugroho, Garin. 2005. "Televisi, musuh di ruang keluarga Indonesia?", in: Garin Nugroho, Seni merayu massa, pp. 160-165. Jakarta: Kompas.

Palmer, Edward L. 1988. Television and America's children: a crisis of neglect. New York: Oxford University Press.

Razel, Micha. 2001. “The complex model of television viewing and educational achievement", The Journal of Educational Research Vol. 94 No. 6 (JulyAugustus): 371-379. [Http://www.jstor.org/stable/27542348, accessed 30-3-2012.]

Rice, Mabel L. and Linda Woodsmall. 1988. “Lessons from television: children's word learning when viewing", Child Development Vol. 59 No. 2 (April): 420-429. [Http://www.jstor.org/stable/1130321, accessed 30-3-2012.]

Sarumpaet, Riris K. 1976. Bacaan Anak. Jakarta: Pustaka Jaya.

Sarumpaet, Riris K. 2005. "Realitas Buatan vs Realitas Impian". Paper, National Scholarly Meeting X, Faculty of Graduate Studies, Unpad, 20 September.

Schultze, Quentin J. 1994. Winning your kids back from the media. Downers Grove, IL: InterVarsity Press.

Shin, Annys, Yian Q. Mui, and Nancy Trejos. 2006. “Watching children watch TV", The Washington Post 25 May 2006. [Http://voices.washingtonpost. com/thecheckout/2006/05/watching_children_watch_tv.html, accessed 7-3-2012.]

Yusuf, Iwan Awaluddin. 2010. "Kritik soap opera Indonesia; Menyoal tayangan 'sampah' di televisi". [Http:/ / bincangmedia.wordpress.com/2010/03/ 20/kritik-soap opera-indonesia-menyoal-tanya, accessed 11-4-2010.] 